\title{
Rola kompetencij zawodowych w dopasowanilu kwalifikacji wymaganych w zawodach medycznych w zakresie świadczeń zdrowotnych
}

\author{
Zdzisław Czajka @i) https://orcid.orgy000-0002-9304-7312
}

Instytut Pracy i Spraw Socjalnych, Warszawa

Adres do korespondencji: Instytut Pracy i Spraw Socjalnych, 01-022 Warszawa, ul. Bellottiego 3B

\section{Abstract}

The role of professional competences in matching the qualifications of medical professionals with the requirements of health care services

The aim of the article is to indicate the role of professional competences in adjusting the qualifications of medical workers to the requirements of the patients treatment process. The article presents the activities of EU and the Polish labour ministry aimed at increasing the role of competences in the labour market policy. It also shows exemplary connections of competences with tasks of family nurse, competence profile in 12 selected medical professions, social competences and personality traits, important for the performance of various medical services. Information on competences is contained in the "Information on occupations", prepared by the Ministry of Family, Labour and Social Affairs. The analysis in the article leads to the conclusion, that not all descriptions of competences are adapted to the specificity of medical work. They must not be used as a benchmark for the development of competence profiles in a particular healthcare organization.

\section{Key words: classification of occupations and specializations, competences, information about professions, uualifications, standard of professional qualifications/competences}

Slowa kluczowe: informacja o zawodlach, klasyfiklacja zawodów i specjalności, kompetencje, kwalifikacje, standard kwalifikacij/kompetencji

\section{Wstęp}

W miarę rozwoju badań nad rolą człowieka w procesie pracy zaczęto dostrzegać konkretne zależności między kwalifikacjami pracowników a rezultatami ich pracy oraz korzyści z tego wynikające. Duży wpływ na to miały badania, których wynikiem była teoria kapitału ludzkiego. Według niej kapitał ludzki zawarty w człowieku obejmuje zasób wiedzy, umiejętności, jego predyspozycje (cechy osobowości) oraz wewnętrzną motywację, które razem decydują o każdej działalności człowieka i jej skutkach [1].

Dzięki tej teorii pojawiło się nowe podejście do kwalifikacji i kompetencji. Poprzednio kompetencje utożsamiano tylko $\mathrm{z}$ zakresem obowiązków i uprawnień pracownika. Nawiązując do teorii kapitału ludzkiego, badacze kompetencji dostrzegli w nich także drugi aspekt - zasób wielu czynników (oprócz wiedzy i doświadczenia) decydujących o możliwościach człowieka, a w przypadku pracownika o prawidłowym, zgodnym z normami, procedurami i oczekiwaniami odbiorcy, wykonaniu danej pracy i jej rezultatach. Większość badaczy zajmujących się zarządzaniem zasobami ludzkimi w skład kompetencji zalicza te same elementy, które decydują o kapitale ludzkim. Można więc uznać, że obecne rozumienie kompetencji pracownika odzwierciedla poziom jego kapitału ludzkiego, niektórzy autorzy mówią nawet o synonimie tych pojęć [2].

Warto też zwrócić uwagę na różnice między kwalifikacjami i kompetencjami. Kwalifikacje utożsamiane są bardziej z formalnym wykształceniem (które szybko się dezaktualizuje) i doświadczeniem, nie odzwierciedlają zmian zachodzących $\mathrm{w}$ złożoności prac. Kompetencje są natomiast pojęciem szerszym, oprócz tradycyjnie rozumianych kwalifikacji obejmują zdolności i cechy osobowości ułatwiające wykonywanie pracy, w tym predyspozycje, a także postawy. Aby być kompetentnym, nie wystarczy posiadać udokumentowane dyplomami kwalifikacje, gdyż w danej pracy liczy się umiejętność pracownika wykorzystania wszystkich swoich kompetencji [3].

Celem artykułu jest wskazanie roli kompetencji zawodowych $\mathrm{w}$ dopasowaniu kwalifikacji wymaganych 
W zawodach medycznych ${ }^{1}$ w zakresie świadczeń zdrowotnych. W dalszym ciągu bowiem wymagania konieczne do wykonywania zawodów medycznych ograniczają się do kwalifikacji formalnych (wykształcenie, doświadczenie zawodowe, dokształcanie). Szczegółowej analizie poddano natomiast powiązania zadań z kompetencjami w zawodzie pielęgniarki pielęgniarstwa rodzinnego (Tabela I) i kardiologicznego oraz fizjoterapeuty, profile kompetencji kluczowych w 12 wybranych zawodach medycznych (Tabela II), ważne przy wykonywaniu różnych zadań, kompetencje społeczne (Tabela III) oraz cechy osobowości (Tabela IV).

Analizę oparto na standardach kompetencji opracowanych na początku XXI wieku oraz przygotowanych w latach 2018-2019 przez specjalistów w danym zawodzie i ekspertów „Informacji o zawodach”2. Ze względu na ograniczone ramy artykułu i dość obszerne informacje o każdym opisanym zawodzie medycznym (około 30 stron) szczegółowo omówiono tylko wybrane zawody. W artykule wykorzystano także aktualne przepisy (ustawy i rozporządzenia) dotyczące kwalifikacji i kompetencji wymaganych w zawodach medycznych oraz literaturę i inne informacje na temat tych zawodów, wymienione w Klasyfikacji Zawodów i Specjalności (KZiS).

\section{Rola Klasyfikicaji Zawodów i Snecjalności w gospodarowaniu zasobami ludzkimi}

Aby wyjaśnić rolę kompetencji, trzeba wspomnieć o Klasyfikacji Zawodów i Specjalności. Pierwszym i najważniejszym celem KZiS jest identyfikowanie wszystkich zawodów występujących w kraju za pomocą odpowiednich kodów sześciocyfrowych, konieczne do prowadzenia przez rząd polityki zatrudnienia. Podstawą zakwalifikowania zawodów do poszczególnych grup są kwalifikacje wymagane do ich prawidłowego wykonywania. W tym celu zastosowano cztery poziomy odpowiadające poziomom kształcenia, od podstawowego do wyższego. Właściwe zakwalifikowanie rodzaju pracy występującej w konkretnej organizacji (pracownicy ze względu na stosowany w niej podział pracy mogą wykonywać różne zadania, nie tylko typowe dla danej specjalności) do zawodu w KZiS wymaga krótkiej charakterystyki zadań i wymagań kwalifikacyjnych. Jest to także konieczne ze względu na występujące często rozbieżności między poziomem kwalifikacji danej grupy zawodowej w KZiS a faktycznym wykształceniem pracownika w danym zawodzie.

Dla statystyki zatrudnienia według zawodów (między innymi sporządzania przez wszystkie podmioty gospodarcze sprawozdań dla GUS) takie informacje były wystarczające. Pozwalały ustalić strukturę zatrudnienia w skali gospodarki, branży czy organizacji i podejmować różne działania w ramach polityki zatrudnienia. Do celów racjonalizacji zatrudnienia i zarządzania personelem były jednak niewystarczające, dlatego wśród naukowców pojawiły się koncepcje ich rozszerzania, tworzenia bardziej szczegółowych informacji o zawodach.
Od wielu lat cel KZiS jest znacznie szerszy i obejmuje identyfikowanie i ujednolicenie zawodów na rynku pracy, aktualizowanie struktury zawodów, prowadzenie analiz i statystyki rynku pracy (zatrudnienia i bezrobocia), realizowanie polityki zatrudnienia (pośrednictwa pracy i poradnictwa zawodowego), a także wykonywanie badań w tym zakresie [4]. Sterowanie rynkiem pracy bez informacji o zawodach jest obecnie niemożliwe, gdyż zarówno poszukujący pracy, jak i pracodawcy oczekują takiej wiedzy. Specjaliści od rynku pracy i zarządzania zasobami ludzkimi już w latach dziewięćdziesiątych XX wieku zwrócili uwagę na możliwość wykorzystania KZiS jako szczegółowego narzędzia informacji nie tylko o zakresie zadań wykonywanych w zawodzie, lecz przede wszystkim o wymaganiach kwalifikacyjnych i kompetencjach. Ma to bezpośredni związek z nowym podejściem do kwalifikacji w UE i rozwojem kompetencji, o czym szerzej w dalszej części artykułu.

Ze względu na zmieniającą się strukturę gospodarczą kraju oraz związaną z nią sytuację na rynku pracy (tworzenie się nowych zawodów i zanikanie starych), a także potrzeby polityki zatrudnienia, liczba zawodów w KZiS ulega ciągłym zmianom. W obecnej klasyfikacji uwzględniono nie tylko zawody i specjalizacje, lecz także wiele stanowisk pracy, których wcześniej nie wyodrębniano (ich nazwy nie są synonimami zawodów). KZiS z 1981 roku liczyła 2610 zawodów i specjalności, w 2002 roku zmniejszono ją do 1636 zawodów, natomiast w KZiS z 2014 roku liczba zawodów i specjalności ponownie wzrosła do $2455^{3}$.

Liczba zawodów medycznych w ostatnich 20 latach również poważnie wzrosła. W KZiS z 1995 roku były tylko 53 specjalności lekarskie, 7 specjalności lekarzy dentystów, 2 specjalności farmaceutyczne i 8 specjalności pielęgniarskich. W zawodzie położnej nie wyodrębniono wówczas żadnej specjalności [5]. W obowiązującej obecnie KZiS z 2014 roku oprócz lekarza, lekarza ordynatora oddziału oraz lekarza ze specjalnością I stopnia występuje natomiast 78 specjalności lekarskich. Drugą liczną grupą są pielęgniarki, oprócz pielęgniarki i pielęgniarki oddziałowej występują 24 specjalności. Lekarze dentyści są klasyfikowani w 9 specjalnościach, farmaceuci w 12 specjalnościach, a położne w 7 (oprócz położnej i położnej oddziałowej) [6].

W ostatnich latach pojawiły się też nowe specjalności w zawodach medycznych, takie jak: informatyk medyczny (251901), koordynator badań klinicznych (229902), koordynator pobierania i przeszczepiania tkanek i narządów (325904), technik analityki medycznej (321201), technik sterylizacji medycznej (321104). Od niedawna sporo uwagi poświęca się także konieczności utworzenia nowego zawodu, a raczej stanowiska wspierającego pracę lekarzy. Chodzi o odciążenie ich od prac pomocniczych, związanych z przygotowaniem w szpitalach pacjentów do zabiegów. W niektórych placówkach zatrudniono już w tym charakterze ratowników medycznych, nazywając ich asystentami lekarza ${ }^{4}$. Jeśli formalnie zostaną określone kwalifikacje tego zawodu/ stanowiska, prawdopodobnie znajdzie się on w KZiS. 


\section{Działania zmierzajace do wzrostu roli kwalifiikacji i kompetencji w opisach zawodów}

Wzrost roli kwalifikacji, jak wskazano we wstępie, ma bezpośredni związek z teorią kapitału ludzkiego. W licznych badaniach prowadzonych w różnych krajach wykazano, że im lepsze dopasowanie kwalifikacji pracownika do wymagań pracy (trudności, złożoności) i oczekiwań odbiorcy produktu (usługi), tym wyższa jakość pracy i lepsze wyniki. Konsekwencją tego było wiele działań podejmowanych przez UE $\mathrm{w}$ formie zaleceń i programów, które miały wpływ na projekty krajowe. W ramach Europejskiej Strategii Zatrudnienia przygotowanej na początku XXI wieku rozwojowi kwalifikacji i kompetencji sprzyjały aktywne formy walki z bezrobociem, rozwój kształcenia ustawicznego i aktywizacja zawodowa kobiet [1].

Z kolei w Programie Operacyjnym Kapitał Ludzki na lata 2007-2013 rozwojowi kompetencji sprzyjały priorytety dotyczące: rozwoju zasobów ludzkich (rozwój kadr nowoczesnej gospodarki, wykorzystanie e-learningu do podnoszenia kwalifikacji), wysokiej jakości systemu oświaty (między innymi dostosowanie kształcenia do wymagań rynku pracy, wyrównywanie szans edukacyjnych i rozwoju kompetencji), szkolnictwa wyższego i nauki (między innymi zapewnienie wysokiej jakości kształcenia, podnoszenie kwalifikacji, szczególnie pracowników B+R) [1]. Na wzrost roli kwalifikacji w strategii zatrudnienia i walce $\mathrm{z}$ bezrobociem zwrócił także uwagę Parlament Europejski w zaleceniach z 2008 roku w sprawie ustanowienia europejskich ram kwalifikacji ${ }^{5}$.

W związku z programami UE Departament Rynku Pracy MPiPS przygotował najpierw metodologię tworzenia standardów [7]. Następnie w 2007 roku w ramach Sektorowego Programu Operacyjnego Rozwój Zasobów Ludzkich opracował Krajowe Standardy Kwalifikacji Zawodowych dla 253 zawodów, w tym dla wszystkich specjalizacji pielęgniarskich, sekretarki oraz salowej. Przez kolejne lata przygotowywano Krajowe Standardy Kompetencji Zawodowych (opublikowane w 2013 roku) dla 300 zawodów, w tym dla lekarza i lekarza dentysty oraz promotora zdrowia, specjalisty zdrowia publicznego i rejestratorki medycznej [4]. Oznacza to, że jednocześnie $\mathrm{z}$ zaleceniami UE podjęto prace nad rozszerzeniem informacji o wymaganiach kwalifikacyjnych w wybranych zawodach. Działania resortu pracy miały też związek z sytuacją na rynku pracy w okresie dużego bezrobocia. Specjaliści uznali, że występuje luka kompetencyjna między kandydatami do pracy a oczekiwaniami pracodawców, pogłębiana brakiem informacji o wymaganych przez pracodawców kompetencjach na różnych stanowiskach [8].

W dalszych pracach zakończonych w 2013 roku resort pracy, przygotowując nową metodologię opisów kwalifikacji (które nazwano zgodnie z sugestiami specjalistów i UE kompetencjami), wykorzystał doświadczenia kilku krajów UE w tym zakresie, a także przedsiębiorców, organizacji pracodawców i związków zawodowych [9]. Nowy model opisu nawiązywał też do wprowadzonych $w$ tym okresie przez resorty edukacji oraz nauki i szkolnictwa wyższego efektów kształcenia. Oprócz informacji zawartych w poprzednich modelach opisu zawodów dodano szczegółowe opisy kompetencji, relacje między kompetencjami a poziomem kwalifikacji określonych w Polskiej Ramie Kwalifikacji, odrębnie określono kompetencje społeczne oraz profil kompetencji kluczowych dla zawodu. Model ten, z niewielkimi zmianami, został wykorzystany w przygotowanych w latach 2018-2019 „Informacjach o zawodach” w ramach projektu Infodoradca + .

Trzeba też wspomnieć, że w Strategii Rozwoju Kapitału Ludzkiego do 2020 roku przyjętej przez rząd w 2013 roku jeden z celów szczegółowych dotyczył podniesienia poziomu kompetencji oraz kwalifikacji obywateli [10]. Wśród zadań realizujących ten cel wymieniono między innymi „rozwój krajowego systemu kwalifikacji oraz systemu walidacji (w tym potwierdzenie kompetencji nabytych również poza sferą edukacji formalnej) i systemów gromadzenia oraz transferu osiągnięć edukacyjnych, spójnych z systemami europejskimi". W ramach tego celu przygotowywane są „Informacje o zawodach" w projekcie Infodoradca+, których dotyczy także niniejszy artykuł.

Uwieńczeniem działań na rzecz wzrostu kompetencji w gospodarowaniu czynnikiem ludzkim było uchwalenie przez Sejm w 2015 roku ustawy o Zintegrowanym Systemie Kwalifikacji (ZSK), która wprowadziła Polską Ramę Kwalifikacji (PRK) i Zintegrowany Rejestr Kwalifikacji (ZRK). ZSK opisuje, porządkuje i zbiera różne kwalifikacje zawodowe $\mathrm{w}$ jednym dostępnym rejestrze ZRK. W ustawie wskazano, że ZSK powinien zapewniać: (1) wysoką jakość nadawanych kwalifikacji, (2) możliwość uznawania efektów uczenia się uzyskiwanych w edukacji pozaformalnej i przez uczenie się nieformalne, (3) możliwość etapowego gromadzenia oraz uznawania osiągnięć, (4) dostęp do informacji o kwalifikacjach możliwych do uzyskania w Polsce, (5) możliwość porównania kwalifikacji uzyskanych w Polsce $\mathrm{z}$ kwalifikacjami nadawanymi $\mathrm{w}$ innych krajach UE, a także standardy opisywania kwalifikacji [11].

Realizację ustawy powierzono Polskiej Agencji Rozwoju Przedsiębiorczości (PARP), która podjęła liczne działania związane z lepszym dopasowaniem kompetencji pracowników do potrzeb rynku pracy. Powołano Radę Programową do spraw Kompetencji oraz Rady Sektorowe do spraw Kompetencji, uruchomiono ZRK, stanowiący narzędzie wspierające modernizację systemu kwalifikacji w Polsce, utworzono PRK powiązaną z Europejską Ramą Kwalifikacjí.

\section{Zakres kompetencij zastosowany W „Informacjach o zawodach"}

Każdy zawód umieszczony w KZiS zawiera krótką syntezę jego charakterystyki, wykaz najważniejszych zadań zawodowych oraz ewentualne dodatkowe zadania, nie zawiera natomiast informacji o wymaganiach kwalifikacyjnych. Brak wymagań kwalifikacyjnych wynika z zasad obowiązujących w Polsce, według których dla 
tak zwanych zawodów regulowanych (między innymi medycznych) określają je odpowiednie przepisy (ustawy i rozporządzenia właściwych ministrów), a dla pozostałych zawodów pracodawcy. Dlatego informacje o kwalifikacjach pożądanych w danym zawodzie zamieszcza się w dokumentach dodatkowych, uzupełniających KZiS, jakimi są standardy kwalifikacji/kompetencji zawodowych, opisy zawodów oraz aktualnie przygotowywane „Informacje o zawodach”. Ponieważ obecnie występuje duże rozproszenie informacji o zawodach w różnych dokumentach tworzonych i gromadzonych przez poszczególne instytucje zajmujące się rynkiem pracy i zawodoznawstwem, zaproponowano stworzenie jednego dokumentu, bardzo szczegółowego i kompleksowego, nazwanego „Informacjami o zawodach” [12]. Można go traktować, jako zbiór wymagań i oczekiwań rynku pracy (głównie pracodawców) wobec instytucji kształcenia formalnego i pozaformalnego $\mathrm{w}$ dostarczaniu kandydatów do pracy o wysokich kwalifikacjach.

Pierwsze rozszerzone informacje pojawiły się w 2000 roku w ramach realizowanego przez resort pracy projektu „Doradca 2000”. Zawierały one następujące dane: zadania i czynności zawodowe, środowisko pracy (warunki materialne, społeczne i organizacyjne), wymagania psychologiczne, fizyczne i zdrowotne, warunki podjęcia pracy $\mathrm{w}$ zawodzie, możliwości awansu zawodowego, podjęcia pracy i zatrudnienia oraz zawody pokrewne) ${ }^{7}$. Spośród zawodów medycznych opisane zostały wówczas: fizjoterapeuta, lekarz, lekarz dentysta, pielęgniarka, położna, sanitariusz szpitalny, specjalista promocji zdrowia i edukacji zdrowotnej, specjalista zdrowia publicznego oraz technik analityki medycznej.

W kolejnych pracach prowadzonych przez specjalistów z zawodoznawstwa na zlecenie ówczesnego resortu pracy zakres informacji ulegał zmianie i ostatecznie przyjęto podobny do zastosowanego w „Informacjach o zawodach" [9]. W przygotowanych obecnie ,informacjach" dla 1000 zawodów znajdują się natomiast następujące dane dotyczące kompetencji w zawodzie [12]:

1) wymagania psychofizyczne i zdrowotne (wymagania fizyczne, sensomotoryczne, sprawności i zdolności istotne $\mathrm{w}$ danym zawodzie oraz cechy osobowości szczególnie przydatne w pracy, ułatwiające prawidłowe wykonanie pracy);

2) wykształcenie (poziom, typ szkoły, kierunek), tytuły zawodowe, dodatkowe kwalifikacje (na przykład studia podyplomowe), uprawnienia niezbędne do pracy (na przykład znajomość języka obcego, znajomość programów komputerowych);

3) możliwości rozwoju zawodowego (ścieżka awansu, możliwość potwierdzenia kompetencji);

4) wymagane kompetencje $w$ powiązaniu $z$ najważniejszymi zadaniami (należy określić kompetencje, a następnie przypisać do nich zadania i dla każdego ustalić zakres wiedzy oraz umiejętności);

5) kompetencje społeczne związane $\mathrm{z}$ zakresem zadań (lista kompetencji powinna wskazywać na gotowość pracownika do ponoszenia odpowiedzialności za skutki swoich działań, postępowania ukierunkowanego na jakość pracy, przestrzegania etyki zawodowej, współdziałania w zespole, dbania o własny rozwój zawodowy i pracowników);

6) profil kompetencji kluczowych dla zawodu (obejmuje: umiejętność obsługi komputera i wykorzystania Internetu, umiejętności matematyczne, umiejętność czytania ze zrozumieniem i pisania, sprawność motoryczną, planowanie i organizowanie pracy, wywieranie wpływu/przywództwo, komunikację ustną, współpracę w zespole, rozwiązywanie problemów).

Ze względu na duże znaczenie profilu poświęcono mu $\mathrm{w}$ artykule nieco więcej uwagi. W literaturze profil kompetencji definiowany jest jako zestaw najważniejszych kompetencji dla zawodu lub grupy stanowisk o podobnym rodzaju pracy i jej złożoności oraz podobnej funkcji społecznej i ekonomicznej, gwarantujących wysoki poziom wykonania pracy lub uzyskanych efektów [13]. Zdaniem specjalistów od zarządzania zasobami ludzkimi liczba kompetencji w profilu nie powinna być zbyt mała, gdyż może nie objąć wszystkich ważnych zachowań pracownika, mających wpływ na wysoką jakość wykonania pracy czy oczekiwania klientów. Z opinii specjalistów wynika, że nie można tworzyć jednego profilu kompetencji dla zawodów różniących się zakresem zadań i specjalistycznym wykształceniem oraz pełnioną funkcją [13].

Wybrany przez zespół przygotowujący metodologię opisów zawodów jednolity profil kompetencji kluczowych dla wszystkich zawodów nie spełnia tych warunków. Powodem jest powiązanie kompetencji w opisach zawodów z ośmioma kompetencjami kluczowymi w uczeniu się przez całe życie, zastosowanymi w Europejskiej Ramie Odniesienia, a nie ze specyfiką zadań wykonywanych w zawodzie. Potwierdza to definicja przyjęta przez autorów podręcznika Jak tworzyć informacje o zawodach... [12]. Kompetencje kluczowe są to kompetencje (połączenie wiedzy, umiejętności i kompetencji społecznych) potrzebne w życiu zawodowym i pozazawodowym oraz do bycia aktywnym obywatelem, w integracji społecznej i w zatrudnieniu.

Kompetencje te zostały już wcześniej wykorzystane w podstawie programowej kształcenia ogólnego w różnych typach szkół w Polsce, do określenia umiejętności ponadprzedmiotowych oraz $\mathrm{w}$ podstawie programowej kształcenia w zawodach, do opisania efektów kształcenia wspólnych dla wszystkich zawodów. Ministerstwo Nauki i Szkolnictwa Wyższego również zdefiniowało w 2011 roku efekty kształcenia dla profilu ogólnoakademickiego na podstawie ośmiu kompetencji sformułowanych w UE [9]. Dlatego zespół ekspertów przygotowujący metodologię dla projektu „Infodoradca+” ustalił podobny profil dziewięciu kompetencji dla wszystkich opisanych zawodów. Powoduje to, że dla zawodów wymagających wysokich kwalifikacji niektóre kompetencje z tego profilu (na przykład umiejętność czytania ze zrozumieniem i pisania) są nieistotne.

\section{Snecyfika kwalifikikaji w zawodach medycznych}

Zawody medyczne z racji ciągłych kontaktów z chorymi $\mathrm{i}$ ich rodzinami należą do ważnych społecznie i w związku z tym wymagają nie tylko wiedzy i umiejętności 
określonych w odpowiednich przepisach, lecz także cech osobowości, w tym predyspozycji ułatwiających prawidłowe, bezkonfliktowe wykonanie pracy, przy jednoczesnym zadowoleniu pacjentów. Niestety, te predyspozycje nie są w żadnych przepisach określone, nikt też nie sprawdza ich u kandydatów do zawodów medycznych. Tymczasem praktyka dostarcza licznych przykładów wskazujących, że brak tych predyspozycji obniża w opinii pacjentów poziom świadczonych przez instytucje ochrony zdrowia usług.

Analizując opisy zawodów i specjalności oraz standardy kwalifikacyjne, można dojść do wniosku, że są one bardziej przydatne w tych zawodach, w których zakres zadań jest elastyczny (zależy od ilości pracy, organizacji i podziału pracy), a wymagania kwalifikacyjne określają samodzielnie pracodawcy. Dlatego wśród 1000 zawodów zakwalifikowanych do ,informacji o zawodach" są tylko nieliczni kierownicy i specjaliści, głównie z sektora przedsiębiorstw. Przykładem może być specjalista kadrowiec, od którego w dużych i średnich podmiotach pracodawcy wymagają wykształcenia wyższego, najchętniej ekonomicznego lub prawniczego. W małych firmach o przewadze administrowania personelem, a także z trudnościami z zaspokojeniem wyższych oczekiwań finansowych kandydatów do pracy po studiach, zatrudnia się natomiast kadrowców z wykształceniem średnim.

Aby określić rolę standardów kwalifikacyjnych, profili kompetencyjnych czy opisów zawodów w ochronie zdrowia, trzeba na nie spojrzeć nie tylko od strony zadania, lecz także od strony wymagań kwalifikacyjnych. Sektor ochrony zdrowia jest w tym zakresie nietypowy w stosunku do sektora przedsiębiorstw, gdyż poziom kwalifikacji jest ściśle powiązany $\mathrm{z}$ rodzajem wykonywanej pracy i określony w przepisach. Dlatego zawody medyczne należą do grupy regulowanych przez ustawy. Istnieją ustawy o zawodach lekarza i lekarza dentysty [14], pielęgniarki i położnej [15], fizjoterapeuty [16], przygotowywana jest nowa ustawa o zawodzie farmaceuty. Rozporządzenie Ministra Zdrowia z 2011 roku określa wymagania kwalifikacyjne (rodzaj i poziom wykształcenia oraz liczbę lat pracy) dla 149 stanowisk pracy w działalności podstawowej w podmiotach leczniczych [17]. Wymienione ustawy oraz przepisy wykonawcze Ministra Zdrowia bardzo szczegółowo określają wymagania kwalifikacyjne oraz zasady podwyższania i uzupełniania kwalifikacji.

Regulacje mają zabezpieczyć przed przenikaniem do zawodów medycznych osób o niskich kwalifikacjach, a jednocześnie zapewnić wysoki poziom usług. Zakres zadań jest także ściśle powiązany ze specjalizacją zawodową i określony w odpowiednich przepisach i ,opisy zawodów” na potrzeby rynku pracy muszą być zgodne z tymi przepisami. Specyfika zawodów jest także związana ze specjalizacją zawodową pracowników, które są ściśle określone w przepisach. Praca farmaceuty jest związana z przygotowywaniem i sprzedażą leków. Lekarz danej specjalności nie może wykonywać pracy innej specjalności, podobnie zakres pracy pielęgniarki powinien być zgodny z jej specjalnością. Takich zależności nie ma w zawodach wykonywanych w sektorze przedsiębiorstw. To może - zdaniem autora-zmniejszać zainteresowanie wykorzystaniem „Informacji o zawodach" w formie standardów kompetencyjnych w organizacjach ochrony zdrowia. Czy słusznie?

Brak w przepisach o wymaganiach kwalifikacyjnych tak zwanych kompetencji miękkich, czyli predyspozycji, motywacji wewnętrznej, oraz kompetencji społecznych uzasadnia zainteresowanie się tymi informacjami. Powinny być wykorzystywane w procesie kształcenia w zawodach medycznych, poczynając od sprawdzenia predyspozycji studentów na I roku studiów, a kończąc na ocenie pracy pracowników w tych zawodach. Ponieważ coraz częściej także w ocenie pracy lekarzy i pielęgniarek stosuje się sformalizowane systemy ocen zawierające najważniejsze w danym zawodzie cechy, powinno się przy ich konstruowaniu wykorzystywać informacje zawarte w dokumentach charakteryzujących dany zawód czy specjalność. Specjaliści od KZiS podkreślają, że informacje te powinny być wykorzystywane przez pracodawców w całym procesie kadrowym, od planowania struktury zatrudnienia i rekrutacji nowych pracowników aż do redukcji zatrudnienia. Struktura „Informacji o zawodach” jest bardzo przejrzysta i ,pozwala na szybkie odnalezienie przez zainteresowanych treści niezbędnych do wykorzystania na każdym etapie zarządzania zasobami ludzkimi" [18].

W „Informacjach” dotyczących 1000 zawodów, których opisy zakończono w czerwcu 2019 roku znalazło się 37 zawodów medycznych oraz innych związanych bezpośrednio z ochroną zdrowia, na przykład informatyk medyczny, w tym 22 specjalizacje pielęgniarek [12]. Ponadto dostępne są opisy czterech zawodów wykonane w 2013 roku w ramach projektu ,Standardy kwalifikacji zawodowych" (część z nich wykorzystano w analizie prezentowanej w Tabelach I-IV). Są to zawody: specjalista promocji zdrowia i edukacji zdrowotnej (229102), specjalista zdrowia publicznego (229104), informatyk medyczny (251901) i rejestratorka medyczna (422603). Struktura opisów jest, jak już wcześniej zaznaczono, bardzo podobna do zastosowanej w „Infodoradcy+”.

\section{Powiazanie kompetencji $z$ zadaniami zawodowymi}

Nowym elementem w opisie zawodów jest powiązanie kompetencji z najważniejszymi zadaniami wykonywanymi w danym zawodzie. Według twórców metodologii opisów liczba zadań zawodowych powinna być uzależniona od zakresu i złożoności prac wykonywanych na stanowiskach pracy $\mathrm{w}$ danym zawodzie i nie przekraczać 15. Z kolei liczba kompetencji powinna zależeć od specyfiki pracy w zawodzie, liczby stanowisk pracy oraz wykonywanych zadań i nie przekraczać 4-5. Nazwy kompetencji powinny być pochodną wymagań na stanowiskach pracy [12]. Poniżej podano przykładowe powiązanie wykonywanych zadań z kompetencjami u pielęgniarki rodzinnej, kardiologicznej oraz fizjoterapeuty.

W zawodzie pielęgniarki specjalistki pielęgniarstwa rodzinnego wyodrębniono 12 podstawowych następujących zadań, dla których wyodrębniono cztery kompetencje zawodowe ${ }^{8}$. Zadania te obejmują: organizowanie działań profilaktycznych i promujących zdrowie, 
prowadzenie działań zmierzających do aktywizacji zdrowotnej pacjenta i rodziny, monitorowanie rozwoju dziecka, realizowanie zadań lokalnej polityki prozdrowotnej, gromadzenie informacji metodą wywiadu, obserwacji i pomiarów, pobieranie materiału do testów diagnostycznych, organizowanie opieki pielęgniarskiej w środowisku, organizowanie samoopieki i samopielęgnacji w chorobie i niepełnosprawności, wykonywanie zabiegów pielęgnacyjnych, wykonywanie zabiegów leczniczych, prowadzenie rehabilitacji przyłóżkowej, pokazywanie i doskonalenie ćwiczeń ogólnousprawniających.

Kompetencje zawodowe obejmują zatem: (1), ,organizowanie działań promujących zdrowie i profilaktykę zdrowotną”, (2) „wykonywanie świadczeń diagnostycznych”, (3) „wykonywanie świadczeń pielęgnacyjno-leczniczych”, (4) „wykonywanie świadczeń rehabilitacyjnych". W opisie tego zawodu pierwsza kompetencja obejmuje pierwsze cztery zadania, kompetencja druga kolejne dwa zadania, trzecia zadania 7-10, natomiast czwarta zadania 11 i 12 .

W zawodzie pielęgniarki kardiologicznej wyodrębniono osiem następujących zadań podstawowych ${ }^{9}$ : przeprowadzenie badania podmiotowego i przedmiotowego u pacjenta, obsługa sprzętu do oceny stanu zdrowia chorego, opieka kardiologiczna, rozpoznawanie stanów zagrożenia życia, podawanie różnymi drogami płynów infuzyjnych i leków, współpraca z zespołem terapeutycznym, prowadzenie ewidencji zdrowotnej chorego i jego rodziny, prowadzenie rehabilitacji przyłóżkowej. Wszystkie przyporządkowano do jednej kompetencji zawodowej: ,udzielanie specjalistycznych świadczeń zdrowotnych w odniesieniu do pacjentów z chorobami układu krążenia oraz w kardiologicznych stanach zagrożenia życia" (trzeba przyznać, że nazwę tej kompetencji można było skrócić na przykład do: „udzielanie świadczeń pacjentom z chorobami układu krążenia i w stanach zawałowych").

W zawodzie fizjoterapeuty wyodrębniono natomiast sześć następujących zadań powiązanych z trzema kompetencjami ${ }^{10}$ : diagnozowanie funkcjonalne na podstawie wieloaspektowych ocen stanu pacjenta, kwalifikowanie do terapii na podstawie wyników diagnostyki (powiązane z kompetencją: ,,wyznaczanie zakresu terapii na podstawie diagnostyki funkcjonalnej pacjenta"), planowanie terapii z uwzględnieniem specyfiki zabiegów, prowadzenie zabiegów z zastosowaniem technik manualnych oraz urządzeń wspierających (powiązane z kompetencją: „planowanie oraz prowadzenie zabiegów”), zlecanie wyrobów medycznych dostosowanych do potrzeb i stanu pacjenta, prowadzenie działań profilaktycznych (powiązane z kompetencją: ,pozazabiegowe opiekowanie się pacjentem”). Trzeba przyznać, że w opisach różnych zawodów nie wszystkie zadania są powiązane z odpowiednimi kompetencjami. Przykładowo wśród zadań rejestratorki medycznej jest wymieniona współpraca z instytucjami zewnętrznymi oraz organizowanie współpracy z pacjentem i jego rodziną, ale nie wyodrębniono odpowiedniej kompetencji.

W Tabeli I pokazano przykładowe zależności między zadaniami i kompetencjami tylko dla trzech zadań pielęgniarki specjalistki pielęgniarstwa rodzinnego: prowadzenie działań zmierzających do aktywizacji zdrowotnej pacjenta i rodziny, wykonywanie zabiegów leczniczych oraz pobieranie materiału do testów diagnostycznych. Dotyczą one trzech różnych kompetencji.

Oceniając pokazane w tabeli zależności między kompetencjami a zadaniami, można stwierdzić, że powinny one być przede wszystkim wykorzystywane jako materiał poglądowy $\mathrm{w}$ trakcie studiów pielęgniarskich, a także w procesie rekrutacji i selekcji kandydatek do pracy $w$ tym zawodzie oraz nabywania przez pielęgniarki nowych lub poszerzania już posiadanych kompetencji. Z podanych wyżej informacji o zależnościach między zadaniami a kompetencjami wynika, że przy nieco innym zakresie zadań w danej placówce korzystający z nich praktycy nie powinni ich traktować jako modelowe, lecz jako materiał inspirujący do tworzenia własnych zależności (jeśli zarządzający placówką uznają, że są przydatne).

\section{Profile kompetencij kluczowych}

Jak już wskazano w części artykułu dotyczącej zakresu kompetencji stosowanego w opisach zawodów, według specjalistów od zarządzania personelem profil powinien zawierać najważniejsze, od których zależy właściwe, zgodne z normami, zasadami i oczekiwaniami pacjentów wykonanie świadczeń medycznych. Tymczasem autorzy opisów przyjęli jednakowy dla wszystkich zawodów model kompetencji, aby wskazać, że w każdym zawodzie występują takie same kompetencje kluczowe, natomiast różny jest stopień ich ważności. Można się domyślać, że autorom chodziło o wskazanie podejmującym decyzje o wyborze zawodów, w którym dane kompetencje (na przykład zdolności, predyspozycje) są mniej ważne, a w którym bardzo istotne, natomiast poszukującym pracy (posiadającym różne kompetencje, a więc kwalifikacje i zdolności), w którym zawodzie ich poziom kompetencji będzie bardziej przydatny.

Dlatego w tym modelu oprócz zakresu kompetencji istotna jest też ich ważność $\mathrm{w}$ danym zawodzie, którą twórcy zgodnie z zasadami stosowanymi w zarządzaniu kompetencjami określili w skali pięciostopniowej. Poziom 1 oznacza kompetencje zbędne, 2 - mało ważne, 3 - istotne, 4 - ważne i 5 - bardzo ważne. Pokazuje to szczegółowo Tabela II zawierająca poziomy wszystkich 9 kompetencji w wybranych 12 zawodach medycznych. Wynika z niej, że między zawodami pokazanymi w tej tabeli występują znaczne różnice w poziomie ich ważności.

Z tabeli wynika, że większość kompetencji w wymienionych zawodach uznano za ważne (poziom 4.0) oraz bardzo ważne (poziom 5). Dysponując profilami kompetencji wszystkich zawodów medycznych, można by wskazać kompetencję najważniejszą oraz najmniej ważną, a także średni poziom ich ważności w różnych zawodach. W podanych przykładowo zawodach najważniejsze są prawie wszystkie kompetencje u pielęgniarek na stanowiskach kierowniczych (specjalistki organizacji i zarządzania), gdzie średni poziom ich ważności wynosi 4.66, natomiast najmniej ważne (średni poziom 3.22) 


\begin{tabular}{|l|l|l|l|l|}
\hline \multicolumn{2}{|c|}{ Kompetencja: organizowanie dzialań promujących zdrowie i profilaktyka zdrowotna. Zadanie: prowadzenie dzialań zmierzających } \\
do aktywizacji zdrowotnej pacjenta i rodziny
\end{tabular}

Tabela I. Przykładowe zależności między kompetencjami i podstawowymi zadaniami u pielęgniarki pielęgniarstwa rodzinnego. Źródło: Informacja o zawodzie - pielęgniarka - specjalista pielęgniarstwa rodzinnego. C:/Users/user/Downloads/Pielegniarka_\%20_specjalista_pielegniarstwa_rodzinnego_222218\%20(1).pdf(dostęp: 20.05.2019).

\begin{tabular}{|c|c|c|c|c|c|c|c|c|c|}
\hline \multirow[b]{2}{*}{ Zawody medyczne } & \multicolumn{9}{|c|}{ Profil kompetencji kluczowych dla zawodu } \\
\hline & 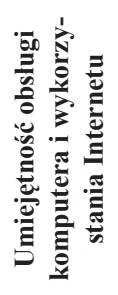 & 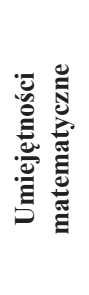 & 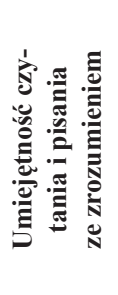 & 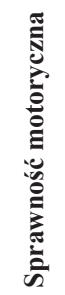 & 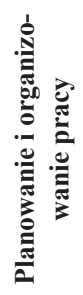 & & 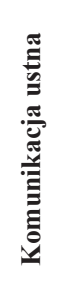 & 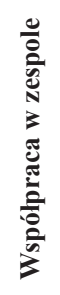 & 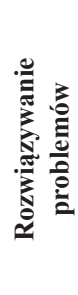 \\
\hline Fizjoterapeuta & 2.0 & 3.0 & 4.0 & 4.5 & 3.5 & 2.0 & 4.0 & 2.0 & 4.0 \\
\hline Specjalista zdrowia publicznego & 4.2 & 3.7 & 4.6 & 3.8 & 4.5 & 4.2 & 4.7 & 4.7 & 4.7 \\
\hline Pielęgniarka (organizacja i zarządzanie) & 5.0 & 3.0 & 5.0 & 4.0 & 5.0 & 5.0 & 5.0 & 5.0 & 5.0 \\
\hline $\begin{array}{l}\text { Pielęgniarka (anestezjologia i intensyw- } \\
\text { na opieka lekarska) }\end{array}$ & 4.0 & 3.0 & 4.0 & 3.0 & 5.0 & 4.0 & 4.0 & 4.0 & 4.0 \\
\hline Pielęgniarka (pediatria) & 2.0 & 5.0 & 5.0 & 5.0 & 4.0 & 4.0 & 5.0 & 5.0 & 5.0 \\
\hline Pielęgniarka (pielęgniarstwo ratunkowe) & 3.0 & 4.5 & 4.0 & 4.0 & 5.0 & 3.0 & 4.5 & 4.0 & 3.5 \\
\hline Pielęgniarka (pielęgniarstwo rodzinne) & 4.3 & 4.2 & 4.5 & 4.3 & 5.0 & 4.8 & 5.0 & 4.5 & 4.8 \\
\hline Położna & 4.0 & 4.0 & 5.0 & 5.0 & 5.0 & 4.0 & 5.0 & 5.0 & 5.0 \\
\hline Promotor zdrowia i edukacji zdrowotnej & 4.5 & 3.5 & 4.5 & 3.8 & 4.4 & 3.9 & 4.3 & 4.7 & 4.5 \\
\hline Sekretarka medyczna & 5.0 & 5.0 & 5.0 & 4.0 & 5.0 & 3.0 & 5.0 & 5.0 & 4.0 \\
\hline Ratownik medyczny & 3.5 & 4.0 & 4.0 & 3.5 & 4.7 & 4.0 & 4.5 & 5.0 & 4.7 \\
\hline Rejestratorka medyczna & 4.9 & 3.0 & 4.7 & 3.5 & 4.3 & 3.5 & 4.7 & 4.7 & 4.2 \\
\hline
\end{tabular}

Tabela II. Profil kompetencji kluczowych dla wybranych zawodów medycznych i ich ważność.

Źródto: Opracowanie własne na podstawie: www.psz.praca.gov.pl/Documents/ oraz www.praca.gov.pl/rynek-pracy/bazy-standardow-kompetencji-kwalifikacji-i-modulowych-programow-szkolen/(dostęp:21.05.2019). 
u fizjoterapeuty. Można mieć jednak wątpliwości, czy określone przez specjalistów poziomy ważności odpowiadają rzeczywistości, gdy porównamy ważność kompetencji w różnych zawodach.

Przykładowo, czy poziom 3 (kompetencja istotna) dla umiejętności matematycznych u pielęgniarek na stanowiskach kierowniczych nie jest zbyt wysoki, gdyż w dobie informatyki większości takich działań nie wykonuje się „ręcznie”. Podobne wątpliwości dotyczą ważności „umiejętności obsługi komputera i wykorzystania Internetu" u pielęgniarki specjalistki pediatrycznej. Określono je na poziomie 2, a więc jako mało ważne, a umiejętności matematyczne jako bardzo ważne (5), skoro większość informacji dotyczących zdrowia dzieci lekarze zapisują w programach komputerowych. Inna wątpliwość dotyczy ważności kompetencji „rozwiązywanie problemów" u ratownika medycznego, którą oceniono na poziomie 4.7, a u pielęgniarki specjalistki pielęgniarstwa ratunkowego tylko na 3.5 , skoro osoby te często z sobą współpracują.

Z kolei u rejestratorki medycznej ważność ,sprawności motorycznej” oceniono na 3.5 mimo przeważającej pracy siedzącej. Natomiast mimo dominującej pracy samodzielnej za zbyt ważną, zdaniem autora (poziom 4.7), uznano „współpracę w zespole”. Trzeba przyznać, że „współpraca w zespole” otrzymała taki sam poziom jak u promotora zdrowia i edukacji zdrowotnej, mimo iż w tym zawodzie zakres współpracy jest znacznie szerszy, a więc także ważniejszy.

Podobnie mimo rzadko występującego ,planowania i organizowania pracy”, gdyż praca rejestratorki zależy w dużym stopniu od natężenia klientów w różnych godzinach pracy, na przykład przychodni, poziom ważności tej kompetencji ustalono w granicach 4.3. Z porównania profili kompetencji w 12 zawodach może też wynikać wniosek, że niewiele się one różnią pod względem wymagań kompetencyjnych, gdyż prawie wszystkie kompetencje we wszystkich zawodach zespoły przygotowujące te informacje uznały jako ważne (4) i bardzo ważne (5). Czy rzeczywiście kompetencje pielęgniarek na stanowiskach kierowniczych, pielęgniarek specjalistek, specjalisty zdrowia publicznego, a nawet położnej oraz sekretarki medycznej i rejestratorki niewiele się różnią pod względem ważności? Powinno to być przedmiotem badań nad poziomem wymaganych kompetencji w zawodach medycznych.

W związku z przyjętym w „Informacjach o zawodach jednakowym profilem dla wszystkich zawodów warto przypomnieć, że od wielu lat przygotowywane są przez różne instytucje, także w UE, zakresy lub profile kompetencji dla różnych zawodów, także medycznych. Wśród nich są ustalone przez Międzynarodową Radę Pielęgniarek zakresy kompetencji dla pielęgniarki ogólnej i specjalistki [19]. W zaleceniach tej rady termin „kompetencje” obejmuje: (1) wiedzę medyczną, zrozumienie i ocenę działań, (2) zakres umiejętności poznawczych technicznych lub psychomotorycznych i interpersonalnych oraz (3) zespół cech i postaw osobowych. Zakres kompetencji pielęgniarki specjalisty obejmuje trzy sfery: (1) profesjonalizm, etykę zawodową i aspekty praktyczne, (2) świadczenie opieki i zarządzanie nią oraz (3) rozwój profesjonalnych kompetencji, poprawę jakości pracy i osobisty rozwój zawodowy.

W ramach tych sfer Rada ustaliła kompetencje szczegółowe, biorąc pod uwagę zasadę, że pielęgniarka każdej specjalności ma identyczne zakresy kompetencji, które w każdej specjalności będą związane z zakresem wykonywanych zadań. Kompetencje te obejmują: rozliczalność działań (odpowiedzialność za wyniki opieki, diagnozy opieki), etykę zawodową, praktykę zgodną z prawem, najważniejsze zasady opieki (wykorzystywanie najnowszej wiedzy, badań w celu podejmowania decyzji), promocję zdrowia (działania zmierzające do zmniejszenia zachorowalności oraz promowania zdrowego stylu życia i środowiska), ocenę działań (analiza i interpretacja danych w celu postawienia właściwej diagnozy), planowanie opieki zdrowotnej, wdrażanie (różne procedury leczenia oraz interwencje z tym związane), ewaluację (monitorowanie i dokumentowanie procesu leczenia, wykorzystywanie ewaluacji do modyfikacji planu opieki medycznej), komunikację terapeutyczną i relacje interpersonalne, przywództwo i zarządzanie, bezpieczne środowisko opieki (chodzi między innymi o właściwy dobór podawanych leków), opiekę interdyscyplinarną (współpraca z różnymi osobami), delegowanie uprawnień, wzmacnianie profesji (doskonalenie zawodowe), podnoszenie jakości opieki medycznej, kontynuację edukacji.

Oceniając ustalone przez Radę kompetencje, łatwo można stwierdzić, że są one związane ściśle z zawodem pielęgniarki. Warto też dodać, że w dokumencie tym wskazano także przy każdej kompetencji, jakiej dodatkowej wiedzy i umiejętności potrzebuje pielęgniarka specjalista w stosunku do pielęgniarki bez specjalizacji.

Kompetencje w zawodzie pielęgniarki określono także w programach UE dotyczących ich kształcenia. W jednym z programów (Tuning), rozpoczętym w 2006 roku, w którym uczestniczyło 14 krajów, określono pięć następujących grup kompetencji [20]:

1) związane z zawodowymi wartościami i rolą pielęgniarek - w tej grupie chodziło o dwie kompetencje: (a) postępowanie w sposób tolerancyjny, opiekuńczy z poszanowaniem wieku pacjenta, jego płci, kultury, poglądów, religii i stylu życia, w związku z coraz większą liczbą obcokrajowców w danym kraju oraz (b) działania odpowiedzialne i samodzielne, zgodne $\mathrm{z}$ wymaganiami zawodowymi, etycznymi, organizacyjnymi i prawnymi, reagowanie na dylematy etyczno-moralne pacjentów (chorzy oczekują od pielęgniarki profesjonalnej pomocy, zapewnienia bezpieczeństwa $\mathrm{w}$ leczeniu, posiadania kompetencji zawodowych oraz odporności psychicznej);

2) dotyczące praktyki pielęgniarskiej i podejmowania decyzji klinicznych, szczególnie w opiece długoterminowej - chodzi tu o uwzględnianie indywidualnych potrzeb pacjenta przez planowanie opieki we współpracy z pacjentem, jego rodziną, pracownikami ochrony zdrowia i pomocy społecznej, wykonywanie czynności terapeutycznych w bezpieczny sposób, zapewnienie pełnej opieki umożliwiającej pacjentowi 
wykonywanie różnych czynności, kształtowanie u chorego umiejętności radzenia sobie z problemami wynikającymi ze stanu jego zdrowia;

3) poznawcze - umiejętność konfrontacji posiadanej wiedzy interdyscyplinarnej (z medycyny, nauk społecznych, przyrodniczych, informatyki) z doświadczeniem zawodowym, znajomość nowoczesnych metod procesu opieki i pielęgnacji pacjenta, wykorzystanie kompetencji do określania zadań, sposobów i metod działania w procesie pielęgnacji chorego, występowanie w roli pomocnika, doradcy, przewodnika, opiekuna i przyjaciela pacjenta oraz jego rodziny,

4) interpersonalne oraz technologia komunikacji umiejętność doboru i stosowania metod oraz środków komunikowania $\mathrm{z}$ pacjentem i rodziną w celu postawienia diagnozy sytuacji zdrowotnej, szczególnie przy zagrożeniu zdrowia i życia;

5) kierownicze i organizacyjne - umiejętność zorganizowanego, zespołowego działania w opiece i pielęgnacji pacjenta, zmierzającego do osiągnięcia wysokiej jakości działań, wykorzystywanie odpowiednich zasobów i technik (podmiot opieki, zespół pielęgniarski, zespół interdyscyplinarny).

Zakres (profil) kompetencji pielęgniarki określony przez różne instytucje w UE potwierdza opinię autora artykułu, że zastosowany w „Informacjach o zawodach” jednolity profil kompetencji dla wszystkich zawodów jest mało przydatny w określaniu kompetencji miękkich w zawodach medycznych, nie może być też wzorcem dla programów szkoleń.

Oceniając zasadność umieszczenia poszczególnych kompetencji wymienionych w profilu z punktu widzenia zawodów medycznych, łatwo zauważyć, że niektóre (umiejętność obsługi komputera, umiejętności matematyczne, umiejętność czytania ze zrozumieniem i pisania) należą do podstawowych umiejętności w zawodach niewymagających specjalnych kwalifikacji. Trudno sobie obecnie wyobrazić studia i programy studiowania oraz przygotowywania prac dyplomowych bez korzystania z programów informatycznych.

\section{Kompetencje społeczne}

Kompetencje społeczne są najczęściej definiowane w literaturze przedmiotu jako zdolność do rozpoznawania wspólnych interesów, poszanowanie poglądów, motywów i potrzeb innych osób, umiejętność współpracy z ludźmi, skuteczne oddziaływania na nich dla dobra klientów, a także umiejętność rozwiązywania konfliktów [2]. We wspomnianym już poradniku Jak tworzyć informacje o zawodach... przyjęto natomiast definicję nieco szerszą, jako „rozwiniętą w toku uczenia się zdolność kształtowania własnego rozwoju oraz autonomicznego i odpowiedzialnego uczestnictwa w życiu zawodowym i społecznym, z uwzględnieniem kontekstu etycznego własnego postępowania" [12].

Przez długi czas nie doceniano wpływu kompetencji społecznych na jakość wykonanej pracy jako czynnika ułatwiającego realizację zadań zgodnie z oczekiwaniami pacjenta. Dopiero od kilku lat specjaliści od zarządzania zasobami ludzkimi dostrzegli ich ważną rolę, szczególnie w zawodach wymagających ciągłych kontaktów z innymi osobami (obywatelami w urzędach administracji publicznej, klientami w handlu i usługach oraz pacjentami w placówkach ochrony zdrowia i pomocy społecznej). We wszystkich zawodach medycznych praca wymaga ciągłych kontaktów z pacjentami, a ułatwiają je kompetencje społeczne.

W Tabeli III zaprezentowano te kompetencje w 12 zawodach. Ponieważ w opisach różnych zawodów te same kompetencje różnie nazwano, aby porównać je między zawodami, zakwalifikowano różne nazwy tych samych kompetencji do przyjętych w tabeli na zasadzie podobieństwa treści.

Różne nazewnictwo jest skutkiem braku koordynacji opisów tworzonych przez poszczególne zespoły. Przykładem różnych nazw jest kompetencja ,gotowość do podnoszenia kwalifikacji”; u położnej określona jako „gotowość do aktualizowania wiedzy zawodowej i kształtowania umiejętności w dążeniu do profesjonalizmu świadczonych usług pielęgniarskich”, u pielęgniarki pielęgniarstwa ratunkowego jako ,podnoszenie kwalifikacji zawodowych w zakresie ciągłego doskonalenia jakości usług pielęgniarstwa ratunkowego", a u pielęgniarki pediatrycznej jako ,podnoszenie kompetencji zawodowych własnych oraz podległego personelu w kontekście zmian prawnych i nowych regulacji zawodowych". Różne nazewnictwo tych samych kompetencji występuje także w zawodach niewymienionych w tabeli. Przykładowo u pielęgniarki chirurgicznej jest to ,pogłębianie wiedzy i umiejętności zawodowych w systematyczny sposób”. Różne nazwy nie są istotne przy korzystaniu tylko z opisu danego zawodu, natomiast z pewnością zwrócą na nie uwagę osoby porównujące kompetencje w różnych zawodach, między innymi medycznych. Może rodzić się pytanie, czy różne definicje zakresu tych samych kompetencji w różnych zawodach mają na celu podkreślenie na przykład specyfiki wiedzy i umiejętności lub koncentrację uwagi na niektórych działaniach.

$\mathrm{W}$ analizowanych w tym artykule 12 zawodach wyodrębniono 18 kompetencji społecznych. Z ich porównania wynika, że w niektórych zawodach występuje znacznie więcej kompetencji niż w innych. Najwięcej kompetencji społecznych (11) wyodrębniono u pielęgniarki pełniącej funkcje kierownicze (specjalistka organizacji i zarządzania), najmniej zaś (3) u promotora zdrowia i edukacji zdrowotnej. W większości zawodów wskazano 5-7 kompetencji. Oceniając liczbę kompetencji w różnych zawodach, można zauważyć, że nie zależy ona od zakresu wykonywanych zadań, lecz od kreatywności zespołów tworzących te informacje. Wśród wyodrębnionych występują takie kompetencje społeczne, które są istotne prawie we wszystkich zawodach, ale w niektórych ich nie wymieniono.

Jedynie „odpowiedzialność za realizację i skutki podejmowanych działań wobec pacjentów” wskazano we wszystkich zawodach. Potrzeby „gotowości do podnoszenia swoich kwalifikacji zawodowych i nadzorowanego zespołu" nie dostrzeżono natomiast u fizjoterapeuty, specjalisty zdrowia publicznego, promotora zdrowia 


\begin{tabular}{|c|c|c|c|c|c|c|c|c|c|c|c|c|}
\hline \multirow[b]{2}{*}{ Rodzaje kompetencji społecznych } & \multicolumn{12}{|c|}{ Zawody medyczne } \\
\hline & 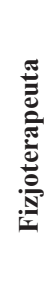 & 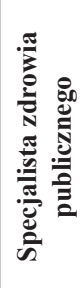 & 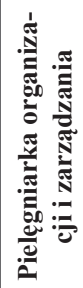 & 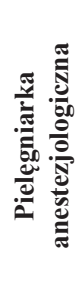 & 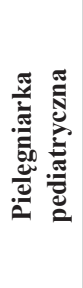 & 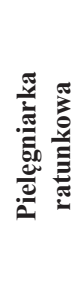 & 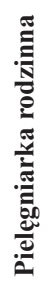 & 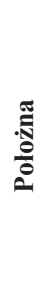 & 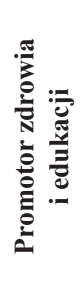 & 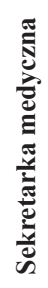 & 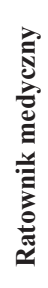 & 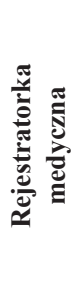 \\
\hline $\begin{array}{l}\text { Dostosowanie zachowań do wymagań i zmian } \\
\text { w środowisku pracy lub w dziedzinie zdrowia }\end{array}$ & & $\mathrm{X}$ & & $\mathrm{X}$ & & & & & & $\mathrm{X}$ & & $\mathrm{X}$ \\
\hline Działania w warunkach stresu i niepewności & & & $\mathrm{X}$ & & & & & & & & $\mathrm{X}$ & \\
\hline $\begin{array}{l}\text { Działanie odpowiedzialne w sytuacjach } \\
\text { konfliktowych }\end{array}$ & & & $\mathrm{X}$ & & & & $\mathrm{X}$ & & & & & \\
\hline $\begin{array}{l}\text { Gotowość do podnoszenia swoich kwalifikacji } \\
\text { zawodowych i nadzorowanego zespołu }\end{array}$ & & & $\mathrm{X}$ & $\mathrm{X}$ & $\mathrm{X}$ & $\mathrm{X}$ & $\mathrm{X}$ & $\mathrm{X}$ & & $\mathrm{X}$ & $\mathrm{X}$ & \\
\hline $\begin{array}{l}\text { Inicjatywy i współpraca w zespole na rzecz } \\
\text { zapobiegania zagrożeniom w zakresie wykony- } \\
\text { wanych zadań }\end{array}$ & & $\mathrm{X}$ & & & & & & & & & $\mathrm{X}$ & \\
\hline $\begin{array}{l}\text { Umiejętność komunikacji w zespole, łatwość } \\
\text { nawiązywania kontaktów z pacjentami }\end{array}$ & $\mathrm{X}$ & & $\mathrm{X}$ & & $\mathrm{X}$ & & & & & & & \\
\hline Myślenie strategiczne i kreatywne & & & & & $\mathrm{X}$ & & & & & & & \\
\hline $\begin{array}{l}\text { Odpowiedzialność za prowadzenie dokumentacji } \\
\text { medycznej pacjentów }\end{array}$ & & & & & & & & & & & & $\mathrm{X}$ \\
\hline $\begin{array}{l}\text { Odpowiedzialność za realizację i skutki podej- } \\
\text { mowanych działań wobec pacjentów }\end{array}$ & $\mathrm{X}$ & $\mathrm{X}$ & $\mathrm{X}$ & $\mathrm{X}$ & $\mathrm{X}$ & $\mathrm{X}$ & $\mathrm{X}$ & $\mathrm{X}$ & $\mathrm{X}$ & $\mathrm{X}$ & $\mathrm{X}$ & $\mathrm{X}$ \\
\hline $\begin{array}{l}\text { Odpowiedzialność za powierzony sprzęt } \\
\text { i narzędzia }\end{array}$ & $\mathrm{X}$ & & & & & & & & & & & \\
\hline $\begin{array}{l}\text { Podejmowanie samodzielnych decyzji dotyczą- } \\
\text { cych zakresu działań stanowiska }\end{array}$ & & & $\mathrm{X}$ & & & & $\mathrm{X}$ & & $\mathrm{X}$ & & & \\
\hline $\begin{array}{l}\text { Przestrzeganie i poszanowanie praw pacjenta, } \\
\text { jego zasad i wyznawanych wartości }\end{array}$ & $\mathrm{X}$ & & $\mathrm{X}$ & $\mathrm{X}$ & & $\mathrm{X}$ & $\mathrm{X}$ & $\mathrm{X}$ & & $\mathrm{X}$ & $\mathrm{X}$ & \\
\hline $\begin{array}{l}\text { Samoocena i weryfikacja działań własnych oraz } \\
\text { (lub) współpracowników }\end{array}$ & $\mathrm{X}$ & & $\mathrm{X}$ & $\mathrm{X}$ & $\mathrm{X}$ & $\mathrm{X}$ & $\mathrm{X}$ & $\mathrm{X}$ & & & & \\
\hline $\begin{array}{l}\text { Tworzenie i rozwój wzorców działań lub progra- } \\
\text { mów dla zachowań prozdrowotnych w obszarze } \\
\text { zakresu stanowiska }\end{array}$ & $\mathrm{X}$ & $\mathrm{X}$ & $\mathrm{X}$ & & & & & $\mathrm{X}$ & $\mathrm{X}$ & & & \\
\hline $\begin{array}{l}\text { Tworzenie klimatu/kultury empatii i zaufania } \\
\text { w zespole lub dla pacjentów }\end{array}$ & & & $\mathrm{X}$ & & & & & & & & & \\
\hline Wspieranie personelu medycznego & & & & & & & & & & $\mathrm{X}$ & & \\
\hline $\begin{array}{l}\text { Współpraca w zorganizowanych warunkach pracy } \\
\text { (zespole) w zakresie wykonywanych zadań }\end{array}$ & & & & & $\mathrm{X}$ & & $\mathrm{X}$ & $\mathrm{X}$ & & $\mathrm{X}$ & $\mathrm{X}$ & $\mathrm{X}$ \\
\hline Zasady etyki zawodowej & $\mathrm{X}$ & $\mathrm{X}$ & $\mathrm{X}$ & $\mathrm{X}$ & $\mathrm{X}$ & $\mathrm{X}$ & $\mathrm{X}$ & $\mathrm{X}$ & & $\mathrm{X}$ & $\mathrm{X}$ & \\
\hline
\end{tabular}

Tabela III. Kompetencje spoteczne w wybranych zawodach medycznych.

Źródto: Opracowanie własne na podstawie: www.psz.praca.gov.pl/Documents/oraz www.praca.gov.pl/rynek-pracy/bazy-standardow-kompetencji-kwalifikacji-i-modulowych-programow-szkolen/(dostęp: 21.05.2019).

i rejestratorki medycznej. Inną niedocenioną kompetencją jest „umiejętność komunikacji w zespole i łatwość nawiązywania kontaktów z pacjentami”, którą wskazano tylko u pielęgniarki pełniącej funkcje kierownicze i u specjalistki pediatrycznej, chociaż jest ważna nawet u rejestratorki medycznej, gdyż od niej pacjent zaczyna kontakt z placówką ochrony zdrowia. Kolejną kompetencją, która nie została doceniona przez niektóre zespoły tworzące opisy zawodów, jest ,przestrzeganie i poszanowanie praw pacjenta, wyznawanych przez niego zasad i wartości”.

Oceniając zasadność posiadania przez pracowników w zawodach medycznych kompetencji społecznych, warto jeszcze zwrócić uwagę na kompetencję ,tworzenie klimatu/kultury empatii i zaufania w zespole lub w stosunku do pacjentów", którą wskazano tylko u pielęgniarki, specjalistki do spraw organizacji i zarządzania oraz na „zasady etyki zawodowej”, których nie wyodrębniono u promotora zdrowia i rejestratorki medycznej. Zdarza się też, że wskazane w „Informacjach” kompetencje społeczne są podane przypadkowo. Przykładem takiej kompetencji u pielęgniarki chirurgicznej (niewymienionej w tabeli) jest ,gotowość do podejmowania aktywności związanych z przeciwdziałaniem dyskryminacji”. Można postawić pytanie, dlaczego taką kompetencję wskazano w dobie 
umiędzynarodowienia ochrony zdrowia tylko u tej pielęgniarki. Można też znaleźć kompetencje przypisane tylko do jednego zawodu, chociaż są ważne we wszystkich zawodach ochrony zdrowia. Taką kompetencją jest ,,podejmowanie wyzwań zawodowych i osobistych w zakresie doskonalenia jakości usług pielęgniarskich" u pielęgniarki anestezjologicznej i intensywnej opieki.

Trzeba też zwrócić uwagę na to, że nazwy niektórych kompetencji społecznych nie są zgodne z definicjami stosowanymi w literaturze przedmiotu. Należy do nich myślenie strategiczne i kreatywne, odpowiedzialność za prowadzenie dokumentacji pacjentów oraz podejmowanie samodzielnych decyzji dotyczących zakresu działań stanowiska pracy, które należą raczej do kompetencji zawodowych. Z powyższej oceny kompetencji społecznych wynika, że nie powinny być one podstawą oceny zakresu tych kompetencji w określonych zawodach medycznych w konkretnej placówce ochrony zdrowia.

\section{Cechy osobowości}

Ważnymi kompetencjami w zawodach medycznych, na które zwrócono uwagę $\mathrm{w}$ artykule ze względu na ich istotną rolę we właściwym wykonywaniu zadań, są cechy osobowości, które przedstawiono w Tabeli IV. Posiadanie pewnych cech osobowości, jak wiadomo, ułatwia pracownikowi wykonywanie pracy, obniża wysiłek psychonerwowy, a pacjent odczuwa większe zadowolenie z wykonanej usługi medycznej. Cechy osobowości nie są istotne we wszystkich zawodach, lecz tylko w tych, w których występuje ciągły kontakt z klientem (handel i usługi), pacjentem (ochrona zdrowia i opieka społeczna), uczniem i rodzicami (szkolnictwo) oraz obywatelem (jednostki administracji publicznej i wymiar sprawiedliwości).

Podobnie jak przy kompetencjach społecznych w „Informacjach o zawodach” te same cechy osobowości są różnie nazwane. Widać też tendencję do podawania

\begin{tabular}{|c|c|c|c|c|c|c|c|c|c|c|c|c|}
\hline \multirow[b]{2}{*}{ Cechy osobowości } & \multicolumn{11}{|c|}{ Zawody medyczne } & \multirow[b]{2}{*}{ 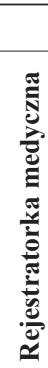 } \\
\hline & 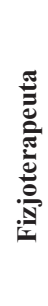 & 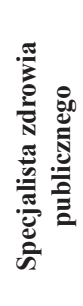 & 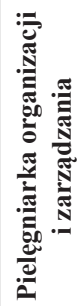 & 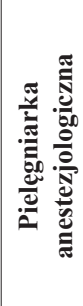 & 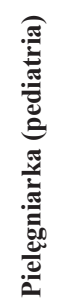 & 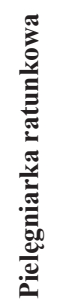 & 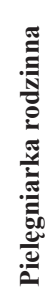 & 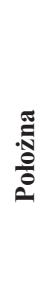 & 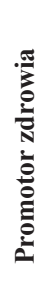 & 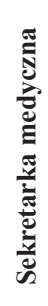 & 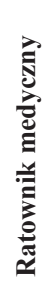 & \\
\hline Asertywność, inicjatywa & $\mathrm{X}$ & & $\mathrm{X}$ & & & & & & & & & $\mathrm{X}$ \\
\hline Cierpliwość, wytrwałość & $\mathrm{X}$ & & & $\mathrm{X}$ & $\mathrm{X}$ & $\mathrm{X}$ & & $\mathrm{X}$ & & & $\mathrm{X}$ & \\
\hline Empatia & $\mathrm{X}$ & & $\mathrm{X}$ & $\mathrm{X}$ & $\mathrm{X}$ & $\mathrm{X}$ & $\mathrm{X}$ & $\mathrm{X}$ & $\mathrm{X}$ & & $\mathrm{X}$ & \\
\hline Gotowość pracy w trudnych warunkach & & & & & & & & & & & $\mathrm{X}$ & \\
\hline Komunikatywność i budowanie dobrych relacji & $\mathrm{X}$ & & $\mathrm{X}$ & $\mathrm{X}$ & & & & $\mathrm{X}$ & $\mathrm{X}$ & $\mathrm{X}$ & & $\mathrm{X}$ \\
\hline Koncentracja i podzielność uwagi & & $\mathrm{X}$ & $\mathrm{X}$ & & & & & & & & $\mathrm{X}$ & $\mathrm{X}$ \\
\hline Kreatywność, wyobraźnia & & $\mathrm{X}$ & & & & $\mathrm{X}$ & & $\mathrm{X}$ & $\mathrm{X}$ & & $\mathrm{X}$ & \\
\hline Obiektywizm & & & $\mathrm{X}$ & & & & & $\mathrm{X}$ & & & & \\
\hline Obowiązkowość, terminowość & & & & & & & $\mathrm{X}$ & & & $\mathrm{X}$ & & \\
\hline Odporność emocjonalna/na stres & $\mathrm{X}$ & & $\mathrm{X}$ & $\mathrm{X}$ & $\mathrm{X}$ & & $\mathrm{X}$ & $\mathrm{X}$ & & $\mathrm{X}$ & $\mathrm{X}$ & $\mathrm{X}$ \\
\hline Odporność na długotrwały wysiłek & & & & & & & & & & & $\mathrm{X}$ & \\
\hline Odpowiedzialność zawodowa & $\mathrm{X}$ & & & $\mathrm{X}$ & $\mathrm{X}$ & & & $\mathrm{X}$ & & & & $\mathrm{X}$ \\
\hline Opiekuńczość & & & $\mathrm{X}$ & & & & $\mathrm{X}$ & $\mathrm{X}$ & & & & \\
\hline Otwartość na zmiany & $\mathrm{X}$ & & & & & & & & & & & \\
\hline Poszanowanie godności człowieka & $\mathrm{X}$ & & $\mathrm{X}$ & & & & & $\mathrm{X}$ & & & & \\
\hline Rzetelność, dokładność & & & & $\mathrm{X}$ & $\mathrm{X}$ & $\mathrm{X}$ & $\mathrm{X}$ & $\mathrm{X}$ & & $\mathrm{X}$ & $\mathrm{X}$ & \\
\hline Samodzielność i samokontrola, dyscyplina & $\mathrm{X}$ & & $\mathrm{X}$ & & $\mathrm{X}$ & & $\mathrm{X}$ & & & $\mathrm{X}$ & $\mathrm{X}$ & \\
\hline Systematyczność, sumienność & & $\mathrm{X}$ & & & & $\mathrm{X}$ & & $\mathrm{X}$ & $\mathrm{X}$ & $\mathrm{X}$ & & $\mathrm{X}$ \\
\hline Tolerancja, wyrozumiałość & $\mathrm{X}$ & & $\mathrm{X}$ & $\mathrm{X}$ & & & & $\mathrm{X}$ & & & & \\
\hline Umiejętność dzielenia się wiedzą & $\mathrm{X}$ & & $\mathrm{X}$ & & & & & & & & & \\
\hline Umiejętność współpracy w zespole & & & & $\mathrm{X}$ & & & & & $\mathrm{X}$ & & & $\mathrm{X}$ \\
\hline Wysoka kultura osobista & & & $\mathrm{X}$ & & & & & $\mathrm{X}$ & & & & $\mathrm{X}$ \\
\hline Zdolności organizacyjne i kierownicze & & $\mathrm{X}$ & $\mathrm{X}$ & & & & & & $\mathrm{X}$ & & & \\
\hline
\end{tabular}

Tabela IV. Cechy osobowości ważne w wybranych zawodach medycznych.

Źródło: Opracowanie własne na podstawie: www.psz.praca.gov.pl/Documents/oraz www.praca.gov.pl/rynek-pracy/bazy-standardow-kompetencji-kwalifikacji-i-modulowych-programow-szkolen/(dostęp: 21.05.2019). 
szerokiego zakresu cech, które mogą być przydatne nie tylko w zawodach medycznych, zamiast wskazywania cech ważnych dla danego zakresu usług medycznych. $\mathrm{Z}$ porównania ich liczby w różnych zawodach wynika, że nie zależy ona od specyfiki pracy w zawodzie, jej trudności, różnorodności zadań czy kontaktów z pacjentem, lecz od inwencji zespołów tworzących te informacje. Łącznie dla 12 analizowanych zawodów wymieniono 30 cech (niektóre, ze względu na bliskoznaczność, podano w tabeli obok siebie). W zawodach o bardziej jednorodnym zakresie zadań, na przykład położna, wymieniono więcej cech osobowości niż w zawodach o pracy bardziej zróżnicowanej, na przykład fizjoterapeuta czy pielęgniarka pielęgniarstwa rodzinnego. Najwięcej cech osobowości (13) wskazano u pielęgniarki do spraw organizacji i zarządzania oraz położnej. Najmniej cech (4) wymieniono natomiast u specjalisty zdrowia publicznego. Identyczną liczbę cech (8) wskazano u rejestratorki medycznej i pielęgniarki anestezjologicznej mimo zdecydowanej różnicy w charakterze pracy na tych stanowiskach.

Oceniając cechy osobowości zawarte w „Informacjach o zawodach" medycznych (wymienionych i niewymienionych w Tabeli IV), można mieć wątpliwości, czy wszystkie są konieczne do zapewnienia wysokiego poziomu usług medycznych. Przykładem może być „opiekuńczość" u pielęgniarki do spraw organizacji i zarządzania oraz ,asertywność" u rejestratorki medycznej. Jednocześnie ważne cechy we wszystkich zawodach medycznych wymieniono tylko w niektórych, na przykład „tworzenie klimatu/kultury empatii i zaufania dla pacjentów” jest ważne w większości zawodów, a wskazano je tylko u pielęgniarki do spraw organizacji i zarządzania oraz chirurgicznej.

\section{Wnioski}

$\mathrm{Z}$ przedstawionych $\mathrm{w}$ artykule informacji dotyczących wymagań kwalifikacyjnych w zawodach medycznych, analizy zakresów zadań i profili kompetencyjnych oraz kompetencji społecznych i cech osobowości ważnych w danym zawodzie wynika kilka wniosków praktycznych. 1. W opisach zawodów medycznych prezentowanych w formie „Informacji o zawodach”, dostępnych na stronie internetowej Publicznych Służb Zatrudnienia (www.psz.praca.gov.pl/rynek-pracy/bazy-danych/ klasyfikacja-zawodow-i-specjalnosci/), jest bardzo wiele szczegółowych informacji o kompetencjach potrzebnych w danym zawodzie. Powinny być one wykorzystywane we wszystkich placówkach ochrony zdrowia, w całym procesie kadrowym, a szczególnie przy pozyskiwaniu nowych pracowników, tworzeniu programów szkoleń, w procesie rozwoju zawodowego oraz przy ustalaniu kryteriów oceniania i dokonywaniu ocen pracowników. Szczególnie ważną rolę, jako narzędzie zarządzania personelem, mogą odegrać w małych placówkach, między innymi w przychodniach, gdzie nie zatrudnia się specjalistów kadrowców. Nie powinny być jednak stosowane automatycznie, bez powiązania z zakresem i podziałem zadań na stanowiskach w konkretnej placówce ochrony zdrowia.
2. Nie wszystkie wymagania kompetencyjne zawarte w „Informacjach o zawodach” są trafnie dobrane przez specjalistów $z$ danego zawodu i ekspertów tworzących te opisy. Powoduje to, że ich wykorzystanie powinno wymagać krytycznego spojrzenia kadrowców placówek ochrony zdrowia. Trzeba je traktować nie jako wzorzec, standard, lecz jako podstawę do tworzenia własnych profili kompetencyjnych dla zawodów w danej placówce. Zwracamy też uwagę osobom odpowiedzialnym w placówkach ochrony zdrowia za gospodarowanie personelem, że nie należy tworzyć zakresu (profilu) kompetencji dla jednego zawodu bez porównania $\mathrm{z}$ kompetencjami $\mathrm{w}$ innym zawodzie. Tworzenie własnych profili kompetencyjnych w każdej placówce jest konieczne także z innego powodu.

3. Otóż badania prowadzone w tym zakresie w wielu krajach wskazują na wzrost roli kompetencji miękkich (społecznych, predyspozycji, cech osobowości, motywacji wewnętrznej) w prawidłowej, zgodnej ze sztuką medyczną, a także oczekiwaniami pacjentów opiece medycznej. Posiadanie tych kompetencji przez pracowników przyczynia się do wyższego poziomu świadczeń zdrowotnych oraz większego zadowolenia pacjentów. Niestety, dotychczas osoby zarządzające personelem medycznym w wielu placówkach ochrony zdrowia nie zwracają na nie należytej uwagi, na przykład przy angażowaniu nowych pracowników oraz w trakcie ich okresowych ocen. Ponieważ każda placówka ochrony zdrowia stosuje własną organizację i podział pracy między stanowiskami, które wymagają różnych kompetencji, „Informacje o zawodach” mogą ułatwić opracowanie własnych profili kompetencyjnych w każdym zawodzie.

4. Można mieć zastrzeżenia do zakresu kompetencji w ,profilach kompetencji” ze względu na ich przydatność w praktyce. Profile są traktowane przez specjalistów od zarządzania jako narzędzie wspomagające wysoką jakość pracy, w tym przypadku świadczeń zdrowotnych. Mimo iż w pracach nad metodologią uczestniczyło wielu specjalistów związanych nie tylko z danym zawodem, lecz także z zarządzaniem zasobami ludzkimi i zawodoznawstwem, wybrano profil kompetencyjny preferowany w UE głównie do oceny poziomu kompetencji społeczeństwa w związku z edukacją przez całe życie. W konsekwencji takiego podejścia $\mathrm{w}$ opisach zawodów brakuje profili kompetencji kluczowych, ważnych w każdym zawodzie medycznym.

\section{Przypisy}

${ }^{1}$ Autor przyjął definicję zgodną z podaną w Ustawie z dnia 15 kwietnia 2011 roku o działalności leczniczej (tekst jednolity Dz.U. z 2018 roku poz. 2190). Według art. 2.1 tej ustawy osoba wykonująca zawód medyczny to osoba uprawniona do udzielania świadczeń zdrowotnych, legitymująca się nabyciem fachowych kwalifikacji do ich udzielania w określonym za- 
kresie lub w określonej dziedzinie medycyny. Świadczeniami zdrowotnymi w myśl tej ustawy są natomiast działania służące zachowaniu, ratowaniu, przywracaniu lub poprawie zdrowia. Według tych definicji do zawodów medycznych można zaliczyć także zawody mające pośredni związek ze świadczeniami zdrowotnymi. Specjaliści od KZiS wymieniają między innymi diagnostę laboratoryjnego, dietetyka, fizyka medycznego, opiekuna medycznego i sanitariusza.

${ }^{2}$ „Informacje o zawodach” są dostępne na: www.psz. praca.gov.pl/rynek-pracy/bazy-danych/klasyfikacja-zawodow-i-specjalnosci w zakładce: INFOdoradca+ Informacje o zawodach (dostęp: 17.03.2019).

${ }^{3}$ Informacja z MRPiPS, Departament Rynku Pracy z 2018 roku; www.psz.praca.gov.pl/documents/10240/6488358/ Klasyfikacja\%20zawodów\%20i\%20specjalnosci (dostęp: 20.03.2019).

${ }^{4}$ Asystent lekarza a zawód pielęgniarki; www.pielęgniarki. info.pl/subcategory/view/id/205 (dostęp: 28.04.2019).

${ }^{5}$ Dz.U. UE C 111 z dnia 6 maja 2008 roku.

${ }^{6}$ Czym jest ZSK; www.kwalifikacje.edu.pl/czym-jest-zsk/?gclid=EAlal. (dostęp: 4.05.2019).

${ }^{7}$ www.psz.praca.gov.pl/rynek-pracy/bazy-danych/doradca-2000 (dostęp: 24.04.2019).

${ }^{8} \mathrm{C}$ :/Users/userDownloads/Pielegniarka_\%20_specjalista_pielegniarstwa_rodzinnego_222218\%20(1).pdf (dostęp: 14.05.2019).

${ }^{9}$ Tamże.

${ }^{10}$ C:/Users/user/Downloads/Fizjoterapeuta_229201\%20(1). pdf (dostęp: 14.05.2019).

\section{Piśmiennictwo}

1. Czajka Z., Gospodarowanie kapitałem ludzkim, Wyd. UwB, Białystok 2011: 17-32.

2. Oleksyn T., Zarzadzanie kompetencjami. Teoria i praktyka, Oficyna Ekonomiczna, Kraków 2006: 17-40.

3. Kwiatkowski S., Symela K. (red.), Standardy kwalifikacji zawodowych. Teoria - metodologia - praktyka, Wyd. Instytut Badań Edukacyjnych, Warszawa 2001.

4. Gruza M., Hordyjewicz T., Klasyfikacja zawodów i specjalności na potrzeby rynku pracy. Tworzenie i stosowanie, MPiPS, Warszawa 2014; www.psz.praca.gov.pl/documents/10240/54723/KZiS\%20Tworzenie\%20i\%20 stosowanie (dostęp: 25.05.2019).

5. Rozporządzenie Ministra Pracy i Polityki Społecznej z dnia 20 kwietnia 1995 roku w sprawie klasyfikacji zawodów i specjalności dla potrzeb rynku pracy oraz zakresu jej stosowania. Załącznik: Tom II. Klasyfikacja właściwa 1 (Dz.U. Nr 48 z 1995 roku poz. 253).
6. Rozporządzenie Ministra Pracy i Polityki Społecznej z dnia 7 sierpnia 2014 roku w sprawie klasyfikacji zawodów i specjalności na potrzeby rynku pracy oraz zakresu jej stosowania (tekst jednolity Dz.U. z 2018 roku poz. 227).

7. Kwiatkowski S., Woźniak I. (red.), Krajowe Standardy Kwalifikacji Zawodowych. Projektowanie i stosowanie, Wyd. Instytut Technologii Eksploatacji, Warszawa 2003: 7-36.

8. Sienkiewicz Ł. (red.), Standardy kwalifikacji zawodowych wobec wymagań rynku pracy, Wyd. IPiSS, Warszawa 2007: 12-21.

9. Raport z prac nad doskonaleniem metodologii opracowywania standardów kompetencji zawodowych, w tym $\mathrm{z}$ badań pilotażowych i z opisem udoskonalonej metodologii, Warszawa-Radom 2013; www.psz.praca.gov.pl/documents/ 10240/3046874/Raport-z-prac...(dostęp: 24.04.2019).

10. Strategia Rozwoju Kapitału Ludzkiego 2020, MPiPS, „Monitor Polski” 2013; poz. 640.

11. Ustawa z dnia 22 grudnia 2015 roku o Zintegrowanym Systemie Kwalifikacji (tekst jednolity Dz.U. z 2018 roku poz. 2153).

12. Symela K., Woźniak I., Jak tworzyć informacje o zawodach funkcjonujacych na rynku pracy, Wyd. Instytut Technologii Eksploatacji, Radom 2018.

13. Filipowicz G., Zarzadzanie kompetencjami zawodowymi, PWE, Warszawa 2004: 8-25

14. Ustawa $z$ dnia 5 grudnia 1996 roku o zawodach lekarza i lekarza dentysty (tekst jednolity Dz.U. z 2018 roku poz. 617).

15. Ustawa z dnia 15 lipca 2011 roku o zawodach pielęgniarki i położnej (tekst jednolity Dz.U. z 2019 roku poz. 576).

16. Ustawa z dnia 25 września 2015 roku o zawodzie fizjoterapeuty (tekst jednolity Dz.U. z 2019 roku poz. 952).

17. Rozporządzenie Ministra Zdrowia z dnia 20 lipca 2011 roku w sprawie kwalifikacji wymaganych od pracowników na poszczególnych rodzajach stanowisk pracy w podmiotach leczniczych niebędących przedsiębiorcami (Dz.U. z 2011 roku Nr 151 poz. 896).

18. Barszcz I., Jabłoński W., Możliwości wdrożenia informacji o zawodach przez pracodawców, „Edukacja Ustawiczna Dorosłych" 2019; 2: 165-174.

19. Zakres kompetencji pielegniarki specjalisty. Zalecenia Międzynarodowej Rady Pielegniarek, Wyd. Polskie Towarzystwo Pielęgniarskie, 2009; www.ptp.na1.pl/pliki/pdf/ICN_Zarys_ Komp_Piel_Spec_2010.pdf (dostęp: 20.06.2019).

20. Bielawska J., Kompetencje zawodowe pielegniarki, „Zeszyty Naukowe Państwowej Wyższej Szkoły Zawodowej w Legnicy" 2012; 8: 5-17.

21. Trawińska-Konador K., Powiazanie informacji o zawodach z kwalifikacjami w Zintegrowanym Systemie Kwalifikacji jako pożadana komplementarność systemowa, „Edukacja Ustawiczna Dorosłych” 2018; 3, 101-109. 